\title{
Pelatihan Dan Pendampingan Pendirian Koperasi Di Perumahan Buana Impian 2 / RW 028 Kelurahan Tembesi-Kecamatan Sagulung- Kota Batam
}

\author{
Sunarto Wage ${ }^{1 *}$, Zakrimal $^{2}$ \\ ${ }^{1}$ Jurusan/Program Studi Akuntansi, Fakultas Ilmu Sosial dan Humaniora \\ ${ }^{2}$ Jurusan/Program Studi Sastra Inggris, Fakultas Ilmu Sosial dan Humaniora \\ ${ }^{1,2}$ Universitas Putera Batam, Jalan R. Soeprapto Muka Kuning, Kibing, Kec. Batu Aji, \\ Kota Batam, Kepulauan Riau 29434 \\ *e-mail : sunarto@puterabatam.ac.id
}

Informasi Artikel

Diterima Redaksi : 25 Maret 2021

Revisi Akhir : 12 April 2021

Diterbitkan Online : 30 Juni 2021

Kata Kunci:

Pelatihan, Pendampingan, Koperasi

\section{PENDAHULUAN}

Ada tiga bentuk badan usaha di Indonesia yaitu: Koperasi, Badan Usaha Milik Negara (BUMN), dan Badan Usaha Milik Swasta (BUMS). Dari tiga jenis badan usaha di Indonesia Koperasi perkembangannya tertinggal jauh dengan Badan Usaha Milik Negara dan Badan Usaha Milik Swasta. Banyak Badan Usaha Milik Negara yang berkembang dengan baik dan menjadi perusahaan yang mampu memberikan kontribusi pada Anggaran Pendapatan dan Belanja Negara (APBN) begitu juga pada Badan Usaha Milik Swasta yang mampu berkembang dengan baik sehingga bisa menciptakan lapangan pekerjaan. Koperasi sebuah bentuk badan usaha sangat sesuai dengan jiwa bangsa Indonesia yakni gotong royong sehingga perlu mendapat dukungan untuk bisa berkembang di tengah tengah masyarakat. Untuk memajukan Koperasi di Indonesia perlu kerjasama semua pihak
Abstrak

Kegiatan pengabdian kepada masyarakat ini berlokasi di Perumahan Buana Impian 2 RW 028 Kelurahan Tembesi, Kecamatan Sagulung, Kota Batam. Di perumahan Buana Impian 2 RW 028 terdapat 4 (empat) Rukun Tetangga (RT) dengan kepala rumah rangga sebanyak 827 KK. Pengabdian kepada masyarakat bertujuan untuk mensosialisasikan tentang penting Koperasi dan cara untuk mendirikan Koperasi. Masyarakat dimotivasi untuk mencintai Koperasi dan mengetahui pentingnya untuk menjadi anggota Koperasi. Manfaat Koperasi tidak hanya secara ekonomi semata tetapi ada unsur gotong royong dan unsur sosial. Kegiatan pengabdian kepada masyarakat dalam bentuk ceramah dan diskusi kepada peserta pelatihan dan dilajutkan dengan pendampingan kepeda peserta. Materi pelatihan terdiri: pendirian koperasi primer, keanggotaan koperasi, perangkat koperasi, modal koperasi, dan jenis koperasi. Setelah mengikuti pelatihan peserta diharapakan termotivasi dan tertarik untuk mendirikan Koperasi di perumahan Buana Impian 2 / RW 028.

mencari sebab dan solusi mengapa Koperasi belum bisa berkembang dengan baik di Indonesia. Kita akan terlebih dahulu membahas tentang koperasi, badan usaha milik negara, dan badan usaha milik swasta agar mengetahui perbedaannya.

Secara umum, Koperasi dapat diartikan sebagai badan usaha yang dimiliki serta dikelola para anggotanya. Ada beberapa pengertian Koperasi menurut beberapa ahli, salah satunya dari Bapak Koperasi, Mohammad Hatta. Menurutnya, Koperasi adalah usaha bersama guna memperbaiki atau meningkatkan kehidupan atau taraf ekonomi berlandaskan asas tolong menolong. Sementara itu menurut Arifinal Chaniago mengartikan Koperasi sebagai suatu perkumpulan yang bekerja sama dalam menjalankan sebuah usaha secara kekeluargaan guna meningkatkan kesejahteraan anggotanya. Pengelolaan sebuah koperasi, para anggotanya dapat 
dengan bebas untuk keluar dan masuk dari badan usaha tersebut. Arti Koperasi oleh Munkner adalah organisasi berasaskan tolong menolong yang mengelola 'urusniaga' secara berkelompok. Tujuannya untuk meningkatkan urusan ekonomi, berbeda dengan asas gotong royong yang bertujuan membangun kebutuhan sosial.

Definisi Badan Usaha Milik Negara di Indonesia adalah ketika sebuah perusahaan saham yang seluruhnya dimiliki negara. Selain itu, BUMN juga berujuk pada perusahaan yang sebagian besar sahamnya atau minimal 51 persen dikuasai oleh pemerintah. Tujuan didirikannya BUMN adalah untuk mewujudkan kesejahteraan masyarakat, serta memenuhi kebutuhan masyarakat. BUMN adalah perusahaan yang juga bertanggung jawab langsung pada pemerintah, dalam hal ini lewat Kementerian BUMN.

Pengertian Badan Usaha Milik Swasta pada dasarnya adalah sebuah badan usaha yang sebagian besar modalnya dimiliki oleh pihak swasta. Tujuan dari BUMS sendiri yaitu mendapatkan keuntungan secara optimal dalam hal pengembangan usaha serta modalnya dan menciptakan lapangan pekerjaan bagi masyarakat.

Sesuai dengan Undang Undang Koperasi No 12 Tahun 2012 Tentang Perkoperasian, pasal 7: (1) Koperasi primer didirikan oleh paling sedikit 20 (dua puluh) orang perseorangan dengan memisahkan sebagian kekayaan pendiri atau anggota sebagai modal awal Koperasi. (2) Koperasi sekunder didirikan oleh paling sedikit 3 (tiga) Koperasi primer.

Keanggotaan Koperasi sesuai Pasal 26: (1) Anggota Koperasi merupakan pemilik dan sekaligus pengguna jasa Koperasi. (2) Keanggotaan Koperasi dicatat dalam buku daftar anggota. (3) Keanggotaan Koperasi bersifat terbuka bagi semua yang bisa dan mampu menggunakan jasa Koperasi dan bersedia menerima tanggung jawab keanggotaan.

Pasal 27: (1) Anggota Koperasi irimer merupakan orang perseorangan yang mampu melakukan perbuatan hukum mempunyai kesamaan kepentingan ekonomi, bersedia menggunakan jasa Koperasi, dan memenuhi persyaratan sebagaimana ditetapkan dalam Anggaran Dasar. (2) Anggota Koperasi sekunder merupakan Koperasi yang mempunyai kesamaan kepentingan ekonomi dan memenuhi persyaratan sebagaimana ditetapkan dalam Anggaran Dasar.

Koperasi mempunyai perangkat organisasi Koperasi yang terdiri atas Rapat Anggota, Pengawas, dan Pengurus. Pasal 32, Rapat Anggota merupakan pemegang kekuasaan tertinggi dalam Koperasi. Pasal 33 Rapat Anggota berwenang: a. menetapkan kebijakan umum Koperasi; b. mengubah Anggaran Dasar; c. memilih, mengangkat, dan memberhentikan Pengawas dan Pengurus; d. menetapkan rencana kerja, rencana anggaran pendapatan dan belanja Koperasi; e. menetapkan batas maksimum pinjaman yang dapat dilakukan oleh pengurus untuk dan atas nama Koperasi; f. meminta keterangan dan mengesahkan pertanggungjawaban pengawas dan pengurus dalam pelaksanaan tugas masing-masing; g. menetapkan pembagian selisih hasil usaha; $h$. memutuskan penggabungan, peleburan, kepailitan, dan pembubaran Koperasi; dan i. menetapkan keputusan lain dalam batas yang ditentukan oleh Undang-Undang ini.

Pasal 48 (1) Pengawas dipilih dari dan oleh anggota pada rapat anggota. (2) Persyaratan untuk dipilih menjadi pengawas meliputi: a. tidak pernah menjadi pengawas atau pengurus suatu Koperasi atau komisaris atau direksi suatu perusahaan yang dinyatakan bersalah karena menyebabkan Koperasi atau perusahaan itu dinyatakan pailit; dan b. tidak pernah dihukum karena melakukan tindak pidana yang merugikan korporasi, keuangan negara, dan/atau yang berkaitan dengan sektor keuangan, dalam waktu 5 (lima) tahun sebelum pengangkatan. (3) Persyaratan lain untuk dapat dipilih menjadi Pengawas diatur dalam Anggaran Dasar.

Pasal 50 (1) Pengawas bertugas: a. mengusulkan calon pengurus; $b$. memberi nasihat dan pengawasan kepada pengurus; $\mathrm{c}$. melakukan pengawasan terhadap pelaksanaan kebijakan dan pengelolaan Koperasi yang dilakukan oleh pengurus; dan d. melaporkan hasil pengawasan kepada aapat anggota. (2) Pengawas berwenang: a. menetapkan penerimaan dan penolakan anggota baru serta pemberhentian anggota sesuai dengan ketentuan dalam Anggaran Dasar; b. meminta dan mendapatkan segala 
keterangan yang diperlukan dari pengurus dan pihak lain yang terkait; c. mendapatkan laporan berkala tentang perkembangan usaha dan kinerja Koperasi dari pengurus; d. memberikan persetujuan atau bantuan kepada pengurus dalam melakukan perbuatan hukum tertentu yang ditetapkan dalam Anggaran Dasar; dan e. dapat memberhentikan Pengurus untuk sementara waktu dengan menyebutkan alasannya.

Pengurus Pasal 55: (1) Pengurus dipilih dari orang perseorangan, baik anggota maupun non-anggota. (2) Orang perseorangan sebagaimana dimaksud pada ayat (1) harus memenuhi persyaratan: a. mampu melaksanakan perbuatan hukum; b. memiliki kemampuan mengelola usaha Koperasi; c. tidak pernah menjadi pengawas atau pengurus suatu Koperasi atau komisaris atau direksi suatu perusahaan yang dinyatakan bersalah karena menyebabkan Koperasi atau perusahaan itu dinyatakan pailit; dan d. tidak pernah dihukum karena melakukan tindak pidana yang merugikan korporasi, keuangan negara, dan/atau yang berkaitan dengan sektor keuangan, dalam waktu 5 (lima) tahun sebelum pengangkatan. (3) Persyaratan lain untuk dapat dipilih menjadi Pengurus diatur dalam Anggaran Dasar.

Pasal 56: (1) Pengurus dipilih dan diangkat pada rapat anggota atas usul pengawas. (2) Untuk pertama kali pengangkatan pengurus dilakukan dengan mencantumkan susunan dan nama pengurus dalam akta pendirian Koperasi sebagaimana dimaksud dalam pasal 10 ayat (2) huruf b. (3) Pengurus diangkat untuk jangka waktu tertentu dengan kemungkinan diangkat kembali. (4) Ketentuan mengenai tata cara pencalonan, pemilihan, pengangkatan, jangka waktu kepengurusan, pemberhentian, dan penggantian pengurus diatur dalam Anggaran Dasar.

Pasal 58 (1) Pengurus bertugas: a. mengelola Koperasi berdasarkan Anggaran Dasar; b. mendorong dan memajukan usaha anggota; c. menyusun rancangan rencana kerja serta rencana anggaran pendapatan dan belanja Koperasi untuk diajukan kepada rapat anggota; d. menyusun laporan keuangan dan pertanggungjawaban pelaksanaan tugas untuk diajukan kepada rapat anggota; e. menyusun rencana pendidikan, pelatihan, dan komunikasi
Koperasi untuk diajukan kepada rapat anggota; f. menyelenggarakan pembukuan keuangan dan inventaris secara tertib; g. menyelenggarakan pembinaan karyawan secara efektif dan efisien; h. memelihara buku daftar anggota, buku daftar pengawas, buku daftar pengurus, Buku daftar pemegang sertifikat modal Koperasi, dan risalah rapat anggota; dan i. melakukan upaya lain bagi kepentingan, kemanfaatan, dan kemajuan Koperasi sesuai dengan tanggung jawabnya dan keputusan rapat anggota. (2) Pengurus berwenang mewakili Koperasi di dalam maupun di luar pengadilan.

Pasal 66 (1) Modal Koperasi terdiri dari setoran pokok dan sertifikat modal Koperasi sebagai modal awal. (2) Selain modal sebagaimana dimaksud pada ayat (1) modal Koperasi dapat berasal dari: a. Hibah; b. Modal Penyertaan; c. modal pinjaman yang berasal dari: 1. Anggota; 2. Koperasi lainnya dan/atau anggotanya; 3 . bank dan lembaga keuangan lainnya; 4. penerbitan obligasi dan surat hutang lainnya; dan/atau 5. Pemerintah dan Pemerintah Daerah. dan/atau d. sumber lain yang sah yang tidak bertentangan dengan Anggaran Dasar dan/atau ketentuan peraturan perundang-undangan.

Pasal 67 (1) Setoran Pokok dibayarkan oleh anggota pada saat yang bersangkutan mengajukan permohonan sebagai anggota dan tidak dapat dikembalikan. (2) Setoran Pokok sebagaimana dimaksud pada ayat (1) harus telah disetor penuh dengan bukti penyetoran yang sah. (3) Ketentuan mengenai persyaratan dan tata cara penetapan Setoran Pokok pada suatu Koperasi diatur dalam Anggaran Dasar.

Pasal 83, jenis Koperasi sebagaimana dimaksud dalam Pasal 82 terdiri dari: a. Koperasi konsumen; b. Koperasi produsen; c. Koperasi jasa; dan d. Koperasi simpan pinjam. Pasal 84 (1) Koperasi konsumen menyelenggarakan kegiatan usaha pelayanan di bidang penyediaan barang kebutuhan anggota dan non-anggota. (2) Koperasi produsen menyelenggarakan kegiatan usaha pelayanan di bidang pengadaan sarana produksi dan pemasaran produksi yang dihasilkan anggota kepada anggota dan non-anggota. (3) Koperasi jasa menyelenggarakan kegiatan usaha pelayanan jasa non-simpan pinjam yang diperlukan oleh anggota dan non-anggota. 
(4) Koperasi simpan pinjam menjalankan usaha simpan pinjam sebagai satu-satunya usaha yang melayani anggota.

Tata cara pendirian koperasi diatur dalam Pasal 12 Permen Koperasi dan UKM No. 9/2018 tentang Penyelenggaraan dan Pembinaan Perkoperasian. Pendirian koperasi dilakukan dengan mengadakan rapat pendirian yang dihadiri para pendiri dan dihadiri oleh pejabat (Kementerian Koperasi dan UKM dan/atau Dinas Provinsi, Dinas Kabupaten/Kota sesuai wilayah keanggotaannya) untuk melakukan penyuluhan terkait koperasi. Untuk koperasi primer dihadiri oleh 20 orang bagi pendirian koperasi primer dan untuk koperasi sekunder dihadiri paling sedikit tiga koperasi yang diwakili oleh pengurus atau anggotanya. Rapat pendirian tersebut, membahas materi rancangan anggaran dasar. Adapun isi dari anggaran dasar dalam akta pendirian koperasi, yaitu: 1. Daftar nama pendiri; 2. Nama dan tempat kedudukan; 3. Maksud dan tujuan serta bidang usaha; 4. Ketentuan mengenai keanggotaan; 5. Ketentuan mengenai rapat anggota; 6. Ketentuan mengenai pengelolaan; 7. Ketentuan mengenai permodalan; 8. Ketentuan mengenai jangka waktu berdirinya; 9 . Ketentuan mengenai pembagian sisa hasil usaha; 9. Ketentuan mengenai sanksi.

\section{METODE}

Pengabdian kepada masyarakat dimaksudkan untuk bisa memberikan pemahaman kepada warga Perumahan Buana Impian $2 \mathrm{RW} 028$ tentang pentingnya koperasi. Masyarakat lebih mengenal Badan Usaha Milik Negara dan Badan Usaha Milik Swasta dibandingkan dengan Koperasi. Permasalahan utama yang dihadapi oleh masyarakat tentang koperasi adalah : (1) Masyarakat belum mengetahui manfaat dari Koperasi, (2) Masyarakat memperoleh informasi yang salah tentang Koperasi akibat ada oknum tertentu yang menyalahgunakan Koperasi, (3) Masyarakat belum mengetahui cara untuk membentuk atau mendirikan koperasi.(4) Masyarakat masih ada yang beranggapan, bahwa koperasi hanya untuk masyarakat yang ekonominya masih lemah, dan masyarakat yang ekonominya sudah mapan tidak perlu dengan koperasi. Pelaksanaan pengabdian kepada masyakat ini dengan dilaksanakan dengan beberapa tahapan diantaranya adalah sebagai berikut:

a) Sebelum dilakukan pengabdian kepada masyarakt terlebih dahulu dilakukan survey di lokasi untuk mengetahui kondisi dan permasalahan yang dihadapi oleh masyarakat Perumahan Buana Impian RW 028 tentang Koperasi dan ekonomi sehari-hari.

b) Memberikan materi atau ceramah kepada peserta pelatihan yang terdiri: pendirian koperasi primer, keanggotaan koperasi, perangkat koperasi, modal koperasi, jenis koperasi, dan cara menyusun laporan keuangan.

Melakukan pendampingan kepada masyarakat warga perumahan buana impian 2 RW 028. Pada kegiatan ini, pengabdian berperan sebagai pendamping yang memberikan arahan dan bimbingan secara teknis kepada peserta pelatihan dan pendampingan kepada masyarakat tentang pendirian sebuah koperas Kegiatan pendampingan kepada peserta pelathan di Perumahan Buana Impian 2 RW 028 dilakukan sebanyak 3 (tiga) kali. Kegiatan pendampingan berfokus pada tercapainya tujuan pelaksanaan pengabdian kepada masyarakat yaitu berdirinya sebuah koperasi. Selain itu dalam kegiatan pendampingan juga dilakukan praktek penyusunan laporan keuangan koperasi dan cara-cara memasarkan produk yang dihasilka oleh anggota koperasi.

\section{HASIL DAN PEMBAHASAN}

Peserta pelatihan dan pendampingan untuk warga di Perumahan Buana Impian 2 RW 028 berjalan lancar dan peserta mengikuti kegiatan dengan seksama dan terjadi diskusi untuk memecahkan permasalahan yang mereka hadapi sehari hari, dan mereka sepakat untuk mendirikan koperasi setelah mengetahui pentingnya koperasi untuk kepentingan bersama. Pelatihan yang diberikan terutama tentang pendirian koperasi dan manfaatnya, juga menyampaikan tentang manajemen keuangan, dan manajemen pemasaran.

a) Pelatihan dan pendampingan ini memberikan materi tentang pendirian koperasi primer, keanggotaan koperasi, perangkat koperasi, modal koperasi, dan jenis koperasi. 
b) Pelatihan dan pendampingan manajemen keuangan. Materi yang sampaikan kepada peserta meliputi; membuat pembukuan, membuat neraca, membuat laporan labar rugi, membuat laporan arus kas, dan perubahan modal.

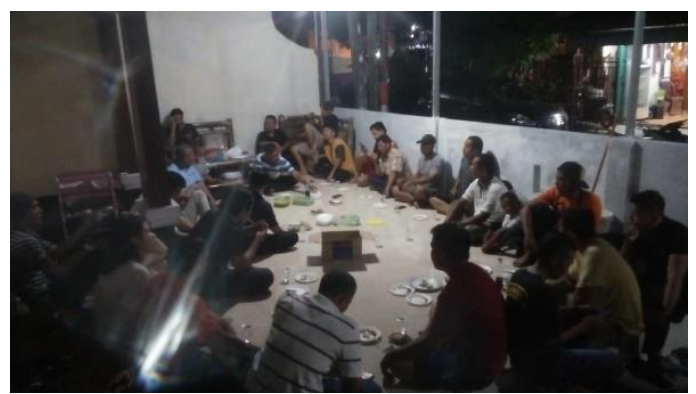

Gambar 1. Pelaksanaan Pelatihan Dan

Pendampingan Pendirian Koperasi

Pelatihan dan pendampingan manajemen pemasaran untuk produk-produk koperasi. Pelatihan dan pendampingan manajemen pemasaran dilaksanakan agar masyarakat yang tergabung pada koperasi mengetahui dan memahami cara dan strategi pemasaran modern dengan memanfaatkan teknologi informasi.

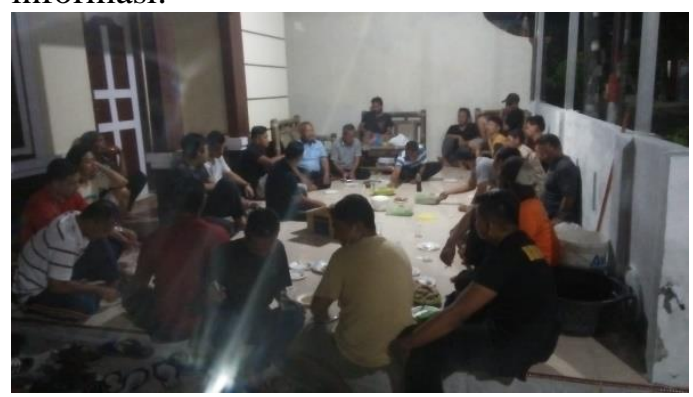

Gambar 2. Penutupan Pelatihan Dan Pendampingan Pendirian Koperasi

\section{KESIMPULAN}

Berdasarkan hasil kegiatan yang telah dilakukan dapat disimpulkan bahwa kegiatan pengabdian kepada masyarakat berupa pelatihan dan pendampingan kepada masyarakat di Perumahan Buana Impian 2 RW 028 berhasil dengan baik. Hal ini berdasarkan diskusi dengan para peserta usai pelatihan, mereka merasa mendapatkan gambaran mengenai koperasi, manajemne keuangan, dan manajemen pemasaran dan berharap ada pelatihan dan pendampingan lebih lanjut sampai terbentuknya sebuah koperasi di Perumahan Buana Impian 2. Dalam diskusi dengan para peserta, mereka belum memiliki pengetahuan mengenai pendirian koperasi dan manfaatnya, manajemen keuangan terutama tentang laporan keuangan, dan manajemen pemasaran.

\section{SARAN}

Pengabdian kepada masyarakat ini sangat berfaat bagi masyarakat di Perumahan Buana Impian 2 RW 028 Kelurahan Tembesi. Setelah mengikuti pelatihan dan pendampingan ini diharapkan para peserta pelatihan bisa mendirikan koperasi di Perumahanan Buana Impian 2. Dalam pelaksanaan pelatihan dan pendampingan ini, masih banyak kekurangannya, diharapkan kedepannya dalam pelaksanaan lebih baik lagi.

\section{UCAPAN TERIMA KASIH}

a) Kepala LPPM Universitas Putera Batam yang telah memfasilitas kegiatan pengabdian kepada Masyarakat.

b) Ketua RT 02 dan Ketua RW 028 Perumahan Buana Impian 2

c) Peserta pelatihan pendirian koperasi

\section{REFERENSI}

[1]. Jenis-jenis Koperasi yang Ada di Indonesia Beserta Contohnya. https://informazone.com

[2]. Koperasi Agro Niaga Jabung (KAN Jabung). https://www.kanjabung.co.id/about/hist ory

[3]. Koperasi-simpan-pinjam-pengertiancontoh-dan-fungsinya. https://money.kompas.com/read/2021/0 3/21/081855026/

[4]. Pengertian-bums-hingga-perantahapannya https://www.jurnal.id/id/blog/

[5]. https://www.cermati.com/artikel/kopera si-pengertian-jenis-fungsi-prinsip-dankeuntungannya-yang-perlu-kamuketahui

[6]. Mengenal BUMN: Definisi, Jenis, Fungsi, dan Tujuan Didirikan. file:///C:/Users/User/Desktop/Koperasi/ BUMN.html

[7]. Undang Undang Koperasi Nomor 17 Tahun 2012

[8]. Wage Sunarto (2020) Pelatihan dan pendampingan kepada pelaku UMKM di Perumahan Buana Impian 2 
Kelurahan Tembesi - Kecamatan

Sagulung - Kota Batam. Jurnal Pengabdian Barelang. Volume 2 Nomor 3 Tahun 2020 e-ISSN: 2656-3959

[9]. Wage Sunarto (2021) Pelatihan mengelola keuangan keluarga pada masa pandemi Covid-19 di Perumahan Buana Impian 2 Kota Batam. Jurnal Puan Indonesia. Edisi Januari 2021 Vol. 2 No. 2multivariate discriminate analysis and artificial neural network. Journal Physical Medical Biology, Vol.3, No. 45, pp. 2859-2871. 